\title{
In Vitro Studies of Horse Umbilical Cord Matrix-Derived Cells: From Characterization to Labeling for Magnetic Resonance Imaging
}

\author{
Anna Lange-Consiglio ${ }^{1}$, Bruna Corradetti ${ }^{2}$, Lucia Rutigliano ${ }^{1}$, Fausto Cremonesi ${ }^{*}{ }^{1}$ and \\ Davide Bizzaro ${ }^{2}$
}

\author{
${ }^{1}$ Università degli Studi di Milano, Faculty of Veterinary Medicine, Large Animal Hospital, Reproduction Unit, Strada \\ dell'Università 6, Località Polledra, 26900 Lodi, Italy \\ ${ }^{2}$ Università Politecnica delle Marche, Department of Biochemistry, Biology and Genetics, Via Brecce Bianche, 60131 \\ Ancona, Italy
}

\begin{abstract}
Despite the increasing use of cell-based therapies for equine orthopedic problems, many questions remain to be answered, such as what is: the optimal cell source for particular injuries, the best timing and route of treatment and the long-term safety and efficacy of the procedure? Previously, equine mesenchymal stem cells (MSCs) have most frequently been isolated from bone marrow (BM) and adipose tissue. However, these cells have limited potential in terms of in vitro proliferation ability and differentiation capacity with increasing donor age and in vitro passage number. In addition, procurement of BM-derived cells in horses requires an invasive BM aspiration procedure which has been associated with pneumopericardium. Fetal adnexa could provide a useful alternative source of MSCs avoiding these limitations. To investigate this, we isolated and characterized presumptive stem cells from the intervascular and perivascular portions of equine umbilical cord matrix using enzymatic digestion. The cells isolated from the intervascular portion showed faster doubling times than cells from the perivascular portion (which are probably more highly differentiated). Cells from both portions expressed MSC mRNA markers $(C D 29, C D 105, C D 44, C D 166)$ and were negative for CD34 and MHC-II. Osteogenic, adipogenic, chondrogenic and neurogenic differentiation were confirmed by specific staining and gene expression.

To investigate the potential of umbilical cord-derived cells for use in cell therapies, pre-clinical experiments involving labeling of cells with magnetic resonance contrast agents (superparamagnetic iron oxide particles - SPIO - and manganese chloride) and the subsequent in vitro study of these were conducted. The SPIO labeling procedure proved to be an efficient and non toxic tool that merits further investigation and the possible development of in vivo studies.
\end{abstract}

Keywords: Umbilical cord matrix, Intervascular and Perivascular cells, Equine, SPIO and Mn labeling, MRI.

\section{INTRODUCTION}

Tendon injuries are a common clinical problem in race horses. Standard treatments are conservative and tendon healing is a prolonged process, with a high risk of re-injury during athletic performance (56\% for jumping horses and $66 \%$ for racing horses) [1]. The use of BM-MSCs undoubtedly represents a new therapeutic approach to the treatment of tendon injuries but the harvesting of bone marrow remains a highly invasive and painful procedure. Furthermore, the number of MSCs isolated, and their proliferation and differentiation potential, declines with increasing donor age [2-4]. Fetal adnexa-derived MSCs could represent a novel class of pluripotent stem cells with characteristics intermediate between embryonic and adult stem cells $[5,6]$. Indeed, the origin of these tissues during the first stages of embryological development supports the theory that they may contain cells which have retained the plasticity of the early embryonic cells from which they are derived.

*Address correspondence to this author at the Università degli Studi di Milano, Faculty of Veterinary Medicine, Large Animal Hospital, Reproduction Unit, Strada dell'Università 6, Località Polledra, 26900 Lodi, Italy; Tel: +390250331150; Fax: +390250331115;

E-mail: fausto.cremonesi@unimi.it
In the horse, as in other Eutherian mammals, the most important sources of MSCs in fetal adnexal tissues are amnion, amniotic fluid and umbilical cord (for isolation of MSCs from cord blood and/or Wharton's Jelly). A recently described stem cell population, called umbilical cord matrix (UCM)-derived stem cells, resides within the abundant extracellular matrix of the umbilical cord. In human medicine, these cells are present in relatively high numbers (significantly greater than the number of MSCs that can be routinely isolated from adult bone marrow), highlighting one of the main advantages of harvesting stem cells from extraembryonic sources [7]. In 2006 Carlin et al., reported, for the first time in veterinary medicine, that porcine Wharton's Jelly (the intervascular portion of UCM) is an easily accessible and inexpensive source of stem cells based on the expression of the three transcription factors (OCT-3/4, SOX2 and NANOG) associated with pluripotency both at the mRNA and protein level [8].

More recently, primitive MSCs have also been isolated from equine UCM [9-12]. Specific pluripotent and MSCmarkers of equine and swine UCM are reported in Table 1. Due to their primitive embryonic stem-cell-like characteristics, UCM-derived cells, when exposed to specific stimuli, have the ability to differentiate into multiple germ layers 
including mesoderm in horses $[9,10,13]$ and ectoderm in pigs $[8,14]$ and horses $[9,11]$.

Table 1. Characteristics of UCM Derived Cells from Domestic Animals

\begin{tabular}{|c|c|c|}
\hline Species & Phenotype & Reference \\
\hline \hline Equine & $\begin{array}{c}\text { Mesenchymal and hematopoietic markers: } \\
\text { CD54+, CD90+, CD105+, CD146+, MHC-I-, } \\
\text { MHC-II-, CD34-, CD45-, CD133-, CD44+, } \\
\text { CD29+ }\end{array}$ & [9-12] \\
& $\begin{array}{c}\text { Embryonic cell markers: OCT4+, SSEA4+, c- } \\
\text { KIT+, SSEA3+ (weak signal), TRA-1-60+ } \\
\text { (weak signal) } \\
\text { Others: SOX2+ }\end{array}$ & \\
\hline Swine & $\begin{array}{c}\text { Embryonic cell markers: OCT-3/4+ } \\
\text { Others: SOX2+, NANOG+ }\end{array}$ & [8] \\
\hline
\end{tabular}

As in human medicine (for review see $[7,15,16]$ ), also in veterinary medicine an important property to evaluate stem cells is to assess their usefulness in allogenic regenerative medicine. To test the immunological properties of UCM-derived cells, Carrade et al., (2010) studied healthy horses following a single intra-articular injection of autologous and allogeneic MSCs from equine UCM and found no significant differences between the degree and type of inflammation elicited by self and non-self-MSC [17].

MSCs are primarily isolated from the UCM by the virtue of their tight adherence to culture dishes, without distinction between intervascular and perivascular stroma. Cell populations obtained in this way appear heterogeneous and may represent a mix of phenotypically, functionally and biochemically different cells. Moreover, in large animals and man it is not possible to track the fate of these cells after injection, while in small animals, such as mice, in vivo tracking with green fluorescent protein (GFP) labeled cells is possible. In larger animals, magnetic resonance imaging (MRI) may emerge as the ideal non-invasive method for monitoring the in vivo behavior of stem cells. In order for transplanted cells to be detectable using MRI, they must be labeled so they can be differentiated from the surrounding tissue. Currently, ferumoxides (a suspension of dextrancoated superparamagnetic iron oxide (SPIO) nanoparticles) and manganese (a heavy metal present as a trace element in the body) are the most commonly used magnetic resonance contrast agents.

If equine allogenic stem cell therapies are to be developed for treatment of musculoskeletal tissue injuries, it is essential to establish whether stem cells from the perivascular or intervascular areas of equine umbilical cord have the better capacity for cell proliferation and plasticity. In addition optimizing labeling of these cells with an MRI contrast marker in order to track them in vivo after transplantation allows investigation of their homing ability, viability and repair potential and may enable the translation of this in vitro approach into clinical trials.

The primary aim of the present study was to isolate cells from the intervascular and perivascular portions of UCM and to compare these two cell lineages by characterization of their specific marker expression patterns, capacity for selfrenewal and potential to differentiate into multiple lineages.

The second aim of this study was to label cells with an MRI contrast marker to verify that they could be detected in situ on an in vitro model of equine tendons and to determine in vitro toxicity of the labeling procedure on cell proliferation and apoptosis.

\section{MATERIAL AND METHODOLOGY}

\subsection{Collection of Samples}

Equine umbilical cords $(n=3)$ were obtained from 3 mares following normal term pregnancies with vaginal delivery in accordance with standard veterinary practice. Before the mare stood up, breaking the cord, a surgical tape was placed at the junction of the cord with the foal and a second tie was tightened approximately $30-40 \mathrm{~cm}$ from the first. The cord portion between the two ties was excised with scissors. The harvested segment of the cords was washed twice in $10 \%$ betadine solution and then in $70 \%$ alcohol and kept at $4{ }^{\circ} \mathrm{C}$ in saline solution supplemented with $4 \mu \mathrm{g} / \mathrm{ml}$ amphotericin (Sigma Aldrich, St. Louis, MO; http://www. sigmaaldrich.com), $100 \mathrm{UI} / \mathrm{ml}$ penicillin (Sigma) and 100 $\mu \mathrm{g} / \mathrm{ml}$ streptomycin (Sigma) until processed within $12 \mathrm{~h}$ of collection.

\subsection{Isolation and Expansion of Presumptive Stem Cells- Like Cells}

After removing the umbilical arteries and vein, the remaining tissue was divided into intervascular and perivascular portions. To isolate presumptive stem cells from each portion, tissues were minced and then digested with collagenase $\left(0.75 \mathrm{mg} / \mathrm{ml}\right.$; Sigma) for $16 \mathrm{~h}$ at $37^{\circ} \mathrm{C}$. After incubation, the suspension was filtered using $80-\mu \mathrm{m}$ filters (Millipore, Milan, Italy; http://www.millipore.com), and washed twice in PBS centrifuging at $250 \mathrm{~g}$ for $10 \mathrm{~min}$ to remove the enzyme. Cells were cultured in high glucoseDulbecco's modified Eagle's medium (HG-DMEM; EuroClone, Milan, Italy; http://www.euroclone.com) supplemented with $10 \%$ fetal bovine serum (FBS; Sigma), $10 \mathrm{ng} / \mathrm{ml}$ epidermal growth factor (EGF) $(100 \mathrm{UI} / \mathrm{ml}), 100$ $\mu \mathrm{g} / \mathrm{ml}$ streptomicin, $0.25 \mu \mathrm{g} / \mathrm{ml}$ amphotericin $\mathrm{B}, 2 \mathrm{mM} \mathrm{L}-$ glutamine (Gibco). Cell cultures were maintained at $5 \%$ $\mathrm{CO}_{2}, 90 \%$ humidity and $38.5^{\circ} \mathrm{C}$ for the experiments described below. The culture medium was replaced after $72 \mathrm{~h}$ to remove non-adherent cells and then replaced twice weekly or as indicated by experimental design. Adherent cells were detached with $0.05 \%$ trypsin-EDTA (EuroClone) just prior to reaching plate confluence $(80-90 \%)$ and then reseeded to maintain the culture.

\subsection{Proliferation Studies}

\subsubsection{Colony Forming Units Fibroblast-Like (CFU-F) Assay}

To assess CFU-F, cells from each portion were seeded at passage (P) 1 at a concentration of $1,800 \mathrm{cells} / \mathrm{cm}^{2}$ in sixwell plates (Euroclone) and kept at $5 \% \mathrm{CO}_{2}, 90 \%$ humidity and $38.5^{\circ} \mathrm{C}$. Colonies were fixed with $4 \%$ formalin, stained with $1 \%$ methylene blue in borate buffer $10 \mathrm{mM}(\mathrm{pH} 8.8$; 
Fluka) at room temperature and washed twice. Cells in colonies with at least 16-20 nucleated cells were counted under an Olympus BX71 microscope.

\subsubsection{Doubling Time (DT)}

Proliferation was evaluated from P1 to P10 on inter- and perivascular-derived cells. The number of viable cells was counted by the Trypan blue dye exclusion method using a Burker chamber. The mean of DT was obtained for each passage according to the following formula $\mathrm{CD}=\log$ $(\mathrm{Ni} / \mathrm{Nf}) / \log _{2}, \mathrm{DT}=\mathrm{CD} / \mathrm{CT}$, where Ni represents seeded cells, Nf number of cells at confluence and CT culture time. Data from three independent experiments are reported.

\subsection{Molecular Characterization}

Specific MSC-markers were investigated using Reverse Transcription (RT) followed by qualitative polymerase chain reaction (PCR) analysis of cells obtained from $\mathrm{P} 1$ to $\mathrm{P} 10$. Total RNA was isolated using TRIZOL $^{\circledR}$ Reagent (Invitrogen) and after the reaction cells were treated with DNase (Sigma). Both steps were performed according to the manufacturer's specifications. RNA concentration and purity were measured using NanoDrop Spectrophotometer (NanoDrop $^{\circledR}$ ND1000). cDNA was synthesized from $200 \mathrm{ng}$ of total RNA using an iScript (Bio-Rad Laboratories, Hercules, CA, USA, http://www.bio-rad.com) retrotranscription kit. Conditions used were $25^{\circ} \mathrm{C}$ for $5 \mathrm{~min}, 42^{\circ} \mathrm{C}$ for 30 min and $85^{\circ} \mathrm{C}$ for $5 \mathrm{~min}$. Qualitative PCR was performed using $1 \mu \mathrm{l}$ of the obtained cDNA in $25 \mu \mathrm{l}$ final volume with DreamTaq DNA Polymerase (Fermentas GmbH, St. Leon Rot, Germany, http://www.fermentas.com) under the following conditions: initial denaturation at $95^{\circ} \mathrm{C}$ for $2 \mathrm{~min}$, 32 cycles at $95^{\circ} \mathrm{C}$ for $30 \mathrm{sec}$ (denaturation), $55-63^{\circ} \mathrm{C}$ for 30 sec (annealing), $72^{\circ} \mathrm{C}$ for $30 \mathrm{sec}$ (elongation) and final elongation at $72^{\circ} \mathrm{C}$ for $10 \mathrm{~min}$. Equine specific primers were initially designed with the open source PerlPrimer software v.1.1.17 based on NCBI Equus caballus sequences or on mammal multi-aligned sequences and subsequently manually improved. Oligonucleotides were designed across an exon-exon junction in order to avoid DNA amplification. Primers were used at a final concentration of $200 \mathrm{nM}$. GAPDH was employed as the reference gene. For differentiation experiments, total RNA was extracted from undifferentiated (control cells) and from induced UCMderived cells, and RT-PCR analysis was performed as described above. Adult equine tissues (bone, fat, cartilage and spinal cord) were employed as positive controls for assessing the expression of osteopontin $(O P N)$ and osteocalcin (bone gamma carboxyglutamate protein; $B G L A P$ ) for osteogenenesis, peroxisome proliferator-activated receptor gamma $(P P A R-\gamma)$ and adiponectin $(A D I P Q)$ for adipogenesis, collagen type II alpha 1 (COL2A1) and aggrecan $(A C A N)$ for chondrogenesis, and glial fibrillary acidic protein $(G F A P)$ and nestin $(N E S)$ for neurogenesis, respectively.

\subsection{Differentiation Assays}

Cells from both intervascular and perivascular portions were seeded at P3 and at a density of $3 \times 10^{3} / \mathrm{cm}^{2}$ for all differentiation studies.

Osteogenic differentiation was assessed by incubating cells until differentiation at $38.5^{\circ} \mathrm{C}$ under $5 \% \mathrm{CO}_{2}$ in modi- fied Romanov et al. (2003) medium [18], composed of HGDMEM medium supplemented with $10 \%$ FBS, $100 \mathrm{U} / \mathrm{ml}$ penicillin, $100 \mu \mathrm{g} / \mathrm{ml}$ streptomycin, $0.25 \mu \mathrm{g} / \mathrm{ml}$ amphotericin B, 2 mM L-glutamine, $10 \mathrm{mM} \beta$-glycerophosphate (Sigma), $0.1 \mu \mathrm{M}$ dexamethasone (Sigma) and $250 \mu \mathrm{M}$ ascorbic acid (Sigma). Non-induced control cells were cultured for the same time in a standard control medium (HG-DMEM supplemented with $10 \% \mathrm{FBS}, 100 \mathrm{U} / \mathrm{ml}$ penicillin, 100 $\mu \mathrm{g} / \mathrm{ml}$ streptomycin, $0.25 \mu \mathrm{g} / \mathrm{ml}$ amphotericin B, $2 \mathrm{mM} \mathrm{L}$ glutamine). Osteogenesis was assessed by conventional von Kossa staining $(1 \%$ silver nitrate and $5 \%$ sodium thiosulfate), which allowed detection of calcium deposits.

For adipogenic differentiation, near-confluent cells were cultured through three cycles of induction/maintenance to stimulate adipogenic differentiation. Each cycle consisted of feeding the UCM-derived cells with supplemented adipogenesis induction medium followed by culture for 3 days $\left(38.5^{\circ} \mathrm{C}, 5 \% \mathrm{CO}_{2}\right)$, and subsequent culture for another 3 days in supplemented adipogenic maintenance medium. The induction medium consisted of modified Romanov et al. (2003) medium [18], composed of HG-DMEM supplemented with $10 \% \mathrm{FBS}, 100 \mathrm{U} / \mathrm{ml}$ penicillin, $100 \mu \mathrm{g} / \mathrm{ml}$ streptomycin, $0.25 \mu \mathrm{g} / \mathrm{ml}$ amphotericin $\mathrm{B}, 2 \mathrm{mM} \mathrm{L-}$ glutamine, $10 \mu \mathrm{g} / \mathrm{ml}$ insulin (Sigma), $150 \mu \mathrm{M}$ indomethacin (Sigma), $1 \mu \mathrm{M}$ dexamethasone and $500 \mu \mathrm{M}$ 3-isobuty-1methyl-xanthine (Sigma). The maintenance medium consisted of HG-DMEM supplemented with $10 \%$ FBS and 10 $\mu \mathrm{g} / \mathrm{ml}$ insulin. Non-induced control cells were cultured for the same time in standard control medium. Adipogenesis was assessed using conventional Oil red $\mathrm{O}$ staining $(0.1 \%$ in $60 \%$ isopropanol) to visualize lipid droplets.

Chondrogenic differentiation was assessed in monolayer culture by incubating cells for 3 weeks in Soncini et al. (2007) modified medium [19], composed of DMEM lowglucose containing $100 \mathrm{nM}$ dexamethasone, $50 \mu \mathrm{g} / \mathrm{ml} \mathrm{L}$ ascorbic acid 2-phosphate, $1 \mathrm{mM}$ sodium pyruvate $(\mathrm{BDH}$ Chemicals Ltd., Poole, UK), $40 \mu \mathrm{g} / \mathrm{ml}$ proline, ITS $(5 \mu \mathrm{g} / \mathrm{ml}$ Insulin, $5 \mu \mathrm{g} / \mathrm{ml}$ Transferrin, $5 \mathrm{ng} / \mathrm{ml}$ Sodium Selenite; Sigma) and $5 \mathrm{ng} / \mathrm{ml}$ TGF- $\beta 3$ (Peprovet, DBA, Italia). Noninduced control cells were cultured for the same time in standard control medium. The presence of metachromatic matrix was demonstrated by Alcian blue staining, $\mathrm{pH}$ 2.5.

Neurogenic induction was performed by culturing cells for $24 \mathrm{~h}$ in a preinduction media consisting of HG-DMEM, $20 \%$ FBS and $1 \mathrm{mM} \beta$-mercaptoethanol (Sigma) $[14,20]$, with neural induction then performed by switching to a medium composed of DMEM plus 2\% FBS, 2\% dimethylsulfoxide (DMSO; Sigma) and $200 \mu \mathrm{M}$ butylated hydroxyanisole (Sigma) for 3 days [21]. Non-induced control cells were cultured for the same time in a standard medium. Conventional Nissl staining $(0.1 \%$ Cresyl violet solution) demonstrated neurogenic differentiation showing increased tigroid bodies.

\subsection{Contrast Agent Cell Labeling}

The labeling protocol was performed as reported by Chung et al., (2009) with some modifications for intervascular cells at P3 [22]. Cells were plated two days before the experiment started. Labeled cells were used in different experiments. 


\subsubsection{Magnetic Labeling of MSCs with SPIO Particles}

Commercially available suspensions of ferumoxide (Endorem, Guerbet S.p.A., Genoa, Italy) contain SPIO particles approximately 80 to $150 \mathrm{~nm}$ in size and a total iron content of $11.2 \mathrm{mg} / \mathrm{ml}$. Intervascular cells were grown until $80-90 \%$ confluence and, at that time, the existing standard medium was removed and fresh DMEM containing $10 \%$ FCS was added. Protamine sulfate (Pro) was prepared as a fresh stock solution of $1 \mathrm{mg} / \mathrm{ml}$ in distilled water. Ferumoxide (SPIO) was diluted in serum-free DMEM to a final concentration of $100 \mathrm{mg} / \mathrm{ml}$.

Protamine sulfate was added to the ferumoxide solution to a final concentration of $5 \mathrm{mg} / \mathrm{ml}$, constituting the Fe-Pro complex. After 3-5 min of intermittent gentle shaking by hand at room temperature, the Fe-Pro complex was added to the freshly applied medium on the cells in a $1: 1 \mathrm{v} / \mathrm{v}$ ratio, to obtain a final concentration of $50 \mu \mathrm{g}$ SPIO particles $/ \mathrm{ml}$ of medium. The medium was removed after $8 \mathrm{~h}$ of incubation, then the cells were washed twice in PBS and a further wash was performed with heparin sodium $(10 \mathrm{U} / \mathrm{ml})$ to remove $\mathrm{Fe}$ Pro complexes from the extracellular surface.

\subsubsection{Prussian Blue Staining}

Prussian blue staining was used to determine iron oxide cell incorporation. Monolayers of SPIO-labeled cells were stained at days 1 and 8 of culture. To perform the staining, the medium was removed from the plate; cells were washed with PBS and fixed with $10 \%$ formalin for $10 \mathrm{~min}$. A solution containing $20 \%$ hydrochloric acid and $10 \%$ potassium ferrocyanide trihyrate (Sigma) was added and cells were incubated for $20 \mathrm{~min}$ at room temperature. Three washes in distilled water were performed before nuclei were counterstained with safranin for $1 \mathrm{~min}$. A further wash was performed to remove excess stain. Cells were observed with a BX 51 microscope (Olympus) and were considered Prussian blue positive if intracytoplasmic blue granules could be detected.

\subsubsection{Labeling of MSCs Using Manganese Chloride $\left(\mathrm{MnCl}_{2}\right)$}

Intervascular cells were grown until $80-90 \%$ confluence, at which time the medium was removed, cells were trypsinized, counted and aliquoted $\left(3 \times 10^{6}\right.$ cells $)$ into $15 \mathrm{ml}$ tubes. $\mathrm{MnCl}_{2}$ solution was freshly prepared at a concentration of $0.1 \mathrm{mM}$ by dissolving $\mathrm{MnCl}_{2}$ in $0.9 \%$ sodium chloride solution. Cells were incubated for $30 \mathrm{~min}$ in $5 \mathrm{ml}$ $\mathrm{MnCl}_{2}$ solution and, for the negative control, cells at a similar concentration were incubated with $5 \mathrm{ml} 0.9 \%$ sodium chloride alone. After incubation, cells were centrifuged at $100 \mathrm{~g}$ for $5 \mathrm{~min}$ at room temperature and washed twice. The last wash was performed with $\mathrm{Ca}^{2+}$ and $\mathrm{Mg}^{2+}$ free PBS.

\subsubsection{Assessment of Cell Proliferation and Apoptosis}

In order to evaluate the effects of the labeling treatment on cell proliferation and apoptosis, SPIO and $\mathrm{MnCl}_{2}$ labeled cells were seeded in 6-wells plates at a density of $1 \times 10^{3}$ cells $/ \mathrm{cm}^{2}$. Growth curves between treated and control (untreated) cells were then compared.

The percentage of apoptotic cells was assessed using an Annexin-V-FITC Apoptosis Detection KIT (Sigma) following the manufacturers' instructions. At days 0,4 and $8,500 \mu$ l of labeled cells $\left(5 \times 10^{5}\right.$ cells) were incubated with 5 $\mu 1$ of Annexin V solution and with $10 \mu 1$ of propidium iodide for $1 \mathrm{~h}$ at room temperature protected from light. Apoptosis rates were evaluated by conventional fluorescence analysis using a BX 51 microscope (Olympus) equipped with a DMU filter set. One hundred cells were analyzed using a combination of $488 / 560 \mathrm{~nm}$ emission. Cells at the early stage
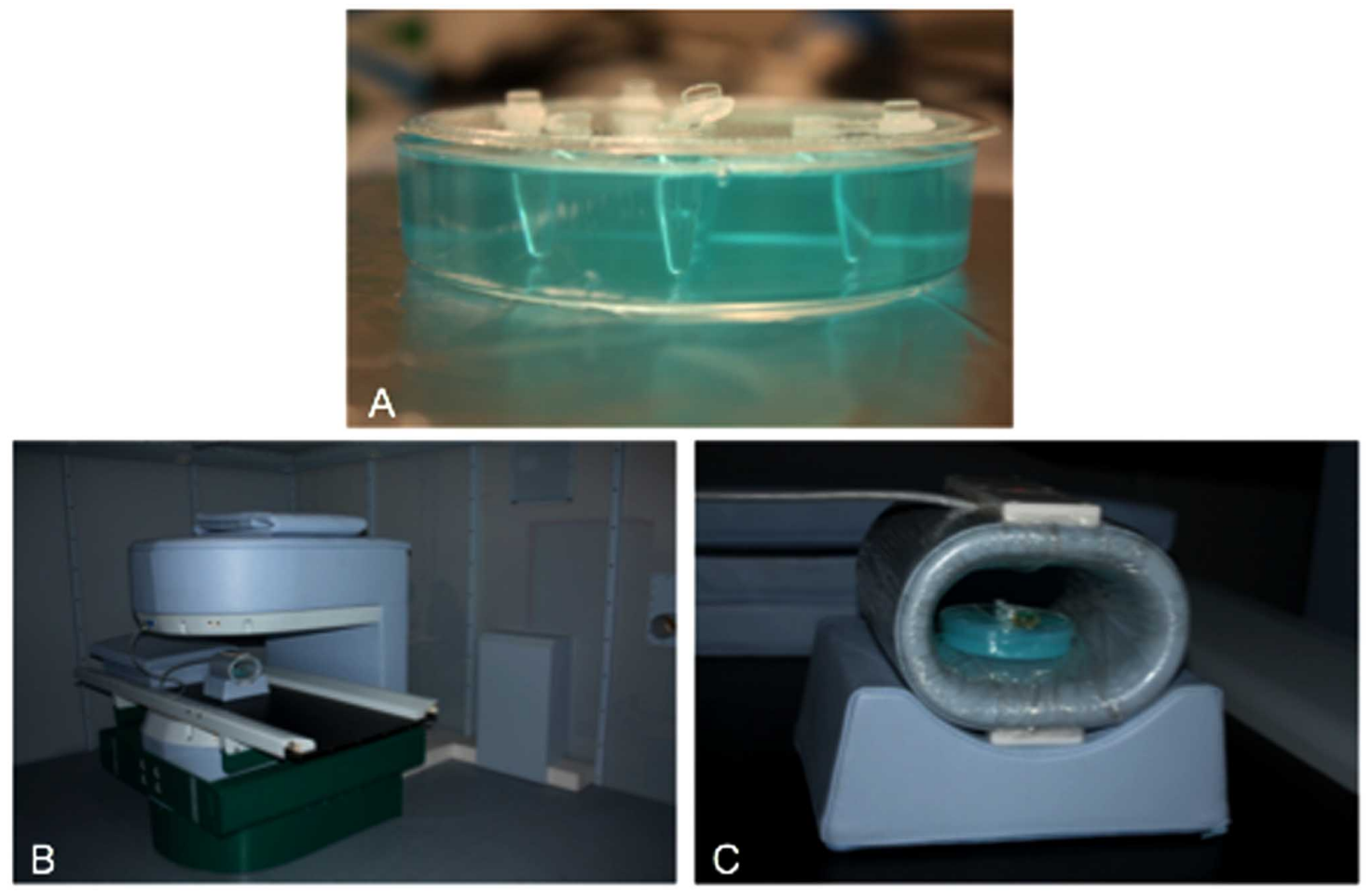

Fig. (1). A) tubes, containing different kinds of cells, embedded in a phantom gel placed directly in the coil of the MRI scanner (B,C). 
of apoptosis stained with the annexin V-FITC alone. Live cells showed no staining with either propidium iodide or Annexin V-FITC. Necrotic cells were stained by both propidium iodide and Annexin V-FITC.

\subsection{MRI in Vitro}

Labeled and non-labeled cells were resuspended in PBS and used for in vitro MRI studies.

The first experiment was performed on cell suspensions. $3 \times 10^{6}$ cells from each experimental group were resuspended in PBS and transferred to a $0.2 \mathrm{ml}$ PCR tube embedded in a phantom gel used to stabilize the tubes and prevent artifacts due to the surrounding air (Fig. 1A). The phantom gel was obtained by dissolving $1 \%$ copper sulphate (Sigma-Aldrich, 61230) into $0.7 \%$ agarose gel (Sigma, A5093). Tubes embedded in the phantom gel were placed directly in the coil of the MRI scanner, as shown in Figs. (1B and 1C).

For the second experiment, fragments of superficial digital flexor tendon were isolated from equine limbs previously collected at the slaughterhouse (Fig. 2A). Each fragment was washed using $0.9 \% \mathrm{NaCl}$ supplemented with gentamicin (Sigma). First, an artificial defect was created by repeated insertion of the large tip of a Tuohy needle in a specific point of the tendon fragment (Fig. 2B), followed by the injection of $1 \mathrm{ml}$ of collagenase $(1 \mathrm{mg} / \mathrm{ml})$ and incubation for $7-8 \mathrm{~h}$ at $37^{\circ} \mathrm{C}$ to enlarge the lesion by enzymatic action (Fig. 2C).

MRI was performed on several sets of isolated tendons before the inoculation of cells as a control. To permit imaging of the same sections, the isolated tendons were fixed on a polystyrene support (MRI inert) covered with graph paper. Subsequently, an ultrasound-guided injection of SPIO, $\mathrm{MnCl}_{2}$-labeled cells or control cells was performed at the site of the artificial lesion. After injection, MRI was again performed on the tendons to visualize the cells.

MRI was performed with a clinical $0.22 \mathrm{~T}$ scanner (MR-J, Paramed, Genova, Italy). SPIO labeled-cells were scanned on $\mathrm{T} 1$ and $\mathrm{T} 2$ weighted sequences; $\mathrm{MnCl}_{2}$ labeled-cells and control cells were scanned on T1 weighted sequences. The parameters used were as follows:

- $\quad$ Gel Scanner: echo time (TR) = from 600 to $800 \mathrm{~ms}$; repetition time $(\mathrm{TE})=15 \mathrm{~ms}$; field of view $(\mathrm{FOV})=$ $256 \times 256$; number of excitations $(\mathrm{NEX})=2 \mathrm{~ms}$; slice thickness $=4 \mathrm{~mm}$; gap $=0.4 \mathrm{~mm}$;

- Tendon Scanner: TR = from 500 to $600 \mathrm{~ms} ; \mathrm{TE}=18$ $\mathrm{ms} ; \mathrm{FOV}=256 \times 256 ; \mathrm{NEX}=2$; slice thickness $=4$ mm; gap $=0,4 \mathrm{~mm}$.

\subsection{Statistical Analysis}

All statistical analyses were performed using Instat 3.00 for Windows (GraphPad software, Inc. La Jolla, CA, USA). Three replicates for each experiment (growth curve, population doublings and CFU) were performed and results are reported as mean \pm standard deviation (SD). One-way analysis of variance (ANOVA) for multiple comparisons by Student Newman Keuls Multiple Comparison Tests was used. A value of $\mathrm{p}<0.05$ was considered to be significant.

\section{RESULTS}

\subsection{Cell Morphology}

UCM-derived cells from each fraction were morphologically homogeneous populations of fibroblast-like cells in the early stage of the primary monolayer culture. However, on reaching confluence, these cells formed spheroid clusters that appeared as three-dimensional structures. This behavior
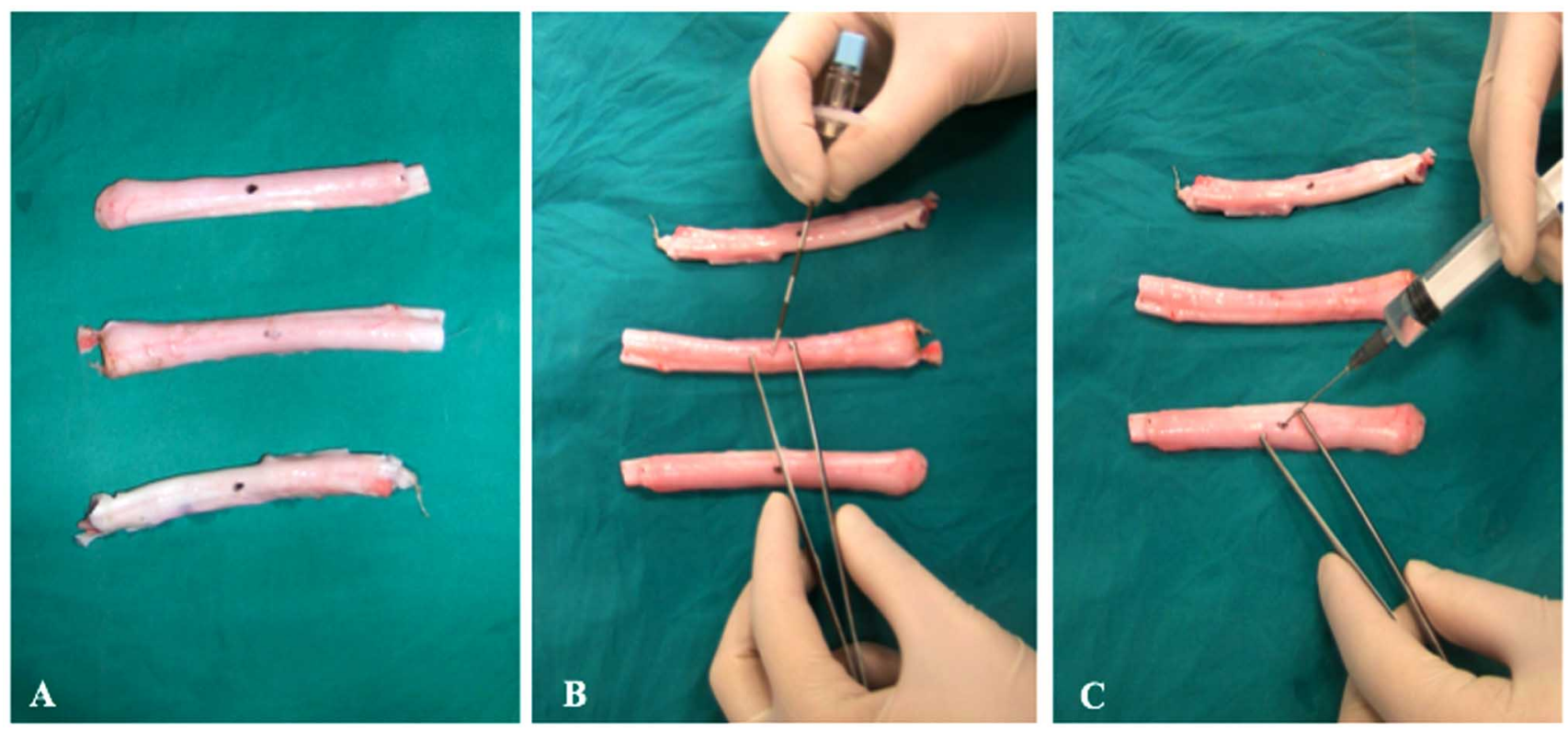

Fig. (2). A) fragments of superficial digital flexor tendon. B) Mechanical creation of an artificial lesion using a Tuohy needle. C) The lesion was increased enzymatically using collagenase. 

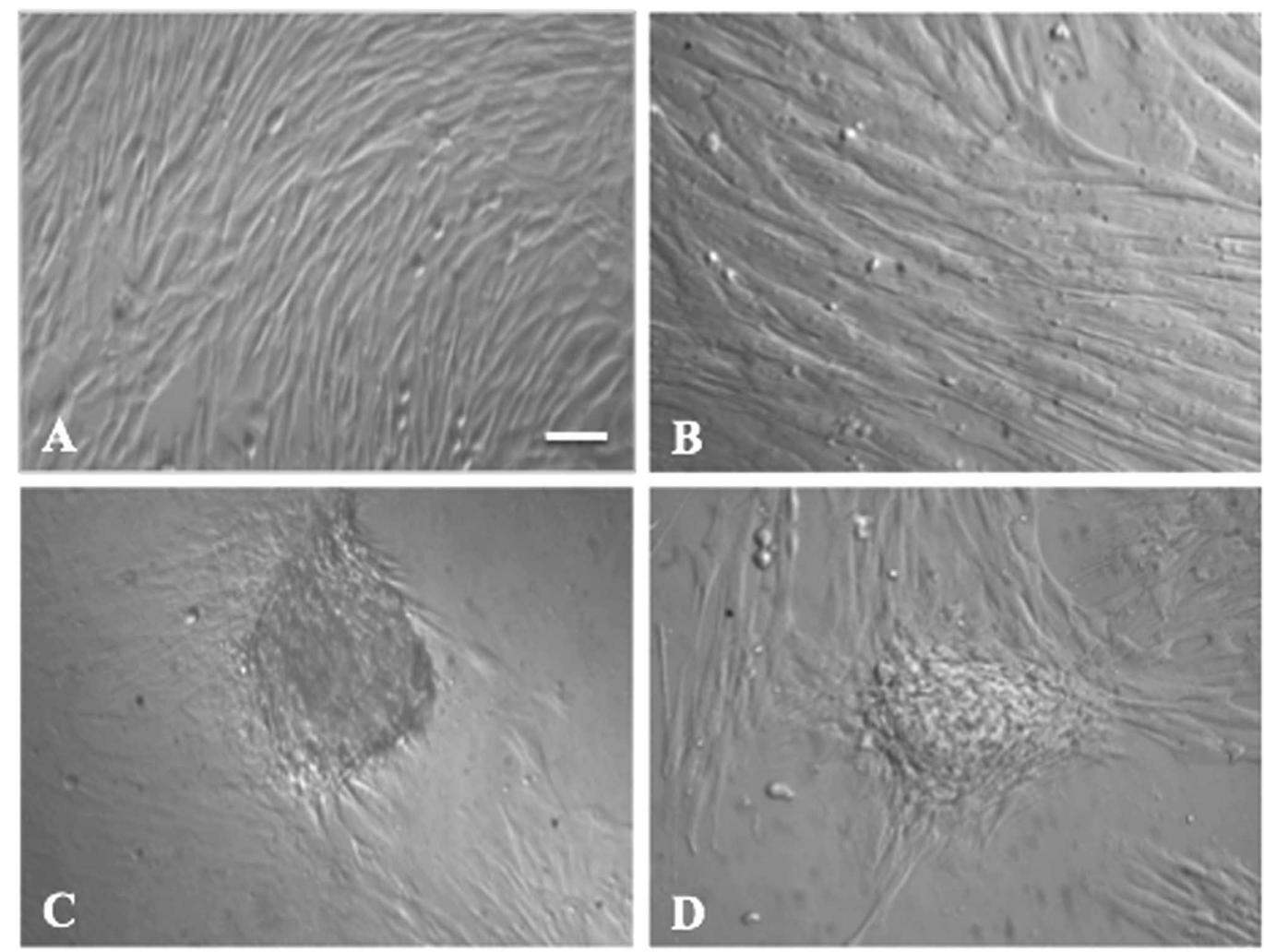

Fig. (3). Cell morphology. Monolayers of Intervascular (A) and Perivascular cells (B), magnification 20x; Cluster of intervascular (C) and perivascular cells (D). Magnification 20x, scale bar $=20 \mu \mathrm{m}$.

was consistently observed when the culture reached the confluence at every subsequent passage (Fig. 3).

\subsection{Proliferation Studies}

Cells isolated from the intervascular and perivascular matrix proliferated over the passages studied, reaching confluence even after 10 passages (the maximum number considered in this study). In intervascular cells, DT significantly decreased $(\mathrm{p}<0.05)$ until P5 compared to P1, remaining constant after the seventh passage. In perivascular cells, values of DT remained constant with a significant $(\mathrm{P}<0.05)$ increase only at the fourth and seventh passage. The mean DT between cell lines at each passage was significantly different $(\mathrm{P}<0.001)$. The mean DT of intervascular cells was $1.60 \pm 0.19$ days compared with $2.64 \pm 0.18$ days for perivascular cells that showed a longer doubling time (Fig. 4).

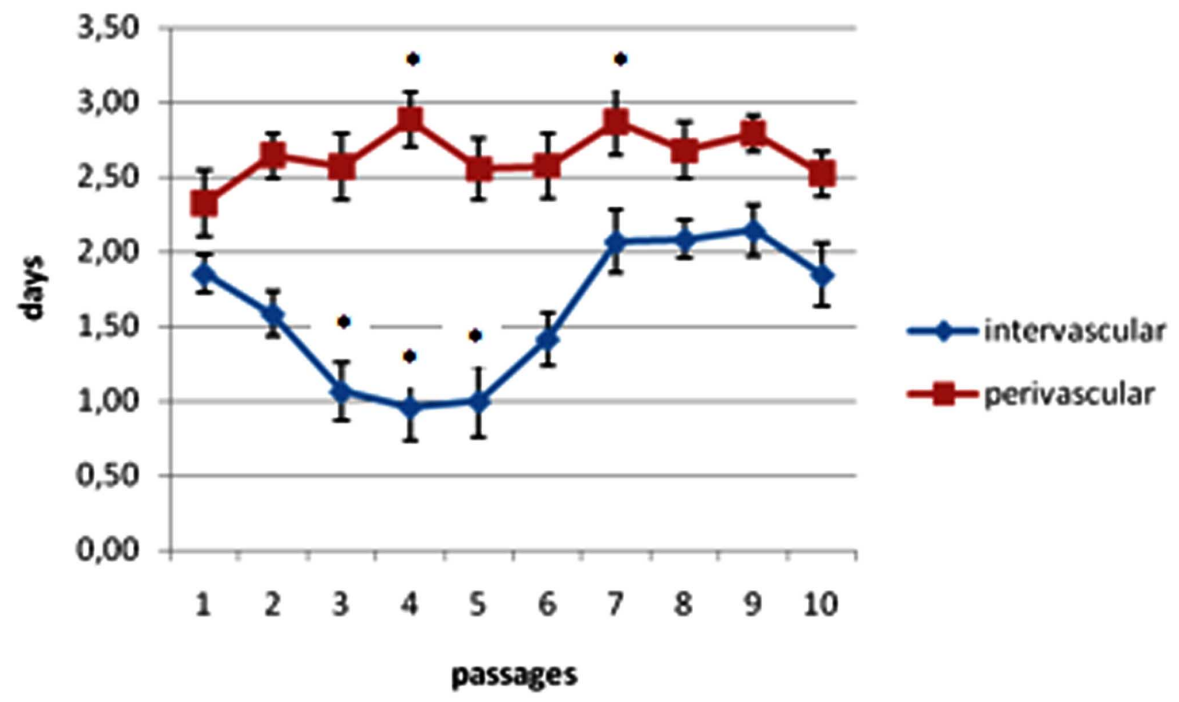

Fig. (4). Doubling times at different passages during cell culture for both, intervascular and perivascular cells. Asterisks represent doubling time means statistically different with respect to P1 in each cell line. 
The number of cell colonies formed was counted at P0. Both cell lines were able to form fibroblastic-colony forming units with values significantly higher $(\mathrm{P}<0.05)$ in intervascular cells than in perivascular cells: $1: 289.93 \pm 7.14$ and $1: 366.11 \pm 9.87$ respectively.

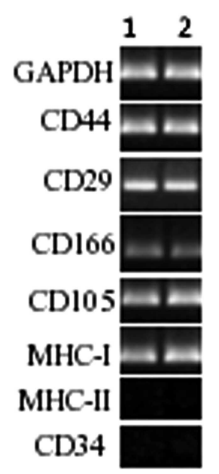

Fig. (5). RT-PCR analysis of mesenchymal (CD44, CD29, CD166, CD105), Major Histocompatibility Complex (MHC) $I$ and $I I$, and hematopoietic (CD34) specific gene expression on intervascular (1) and perivascular (2) derived cells at P1 and P5.

\subsection{Molecular Characterization}

As shown by RT-PCR, each population expressed MSCmarkers (CD29, CD44, CD105, CD166) and lacked hematopoietic ones (CD34 and $C D 14)$ from P0 to P10. MHC-I expression was present on each cell population while $M H C$ II was not (Fig. 5).

\subsection{Differentiation Assay}

All differentiations are represented in Fig. (6A,B).

\subsubsection{Osteogenic Differentiation Potential}

After 10 days of induction, osteogenic differentiation was confirmed by von Kossa staining, which was more intense in intervascular than perivascular cells. The control (non induced cells) was negative for von Kossa staining. RT-PCR analysis of BGLAP mRNA expression confirmed osteogenic induction in both cell lines. However, cells derived from the perivascular portion did not express $O P N$ mRNA.

\subsubsection{Adipogenic Differentiation Potential}

Both cell populations were able to undergo adipogenic differentiation, as demonstrated by the development of

\section{A}
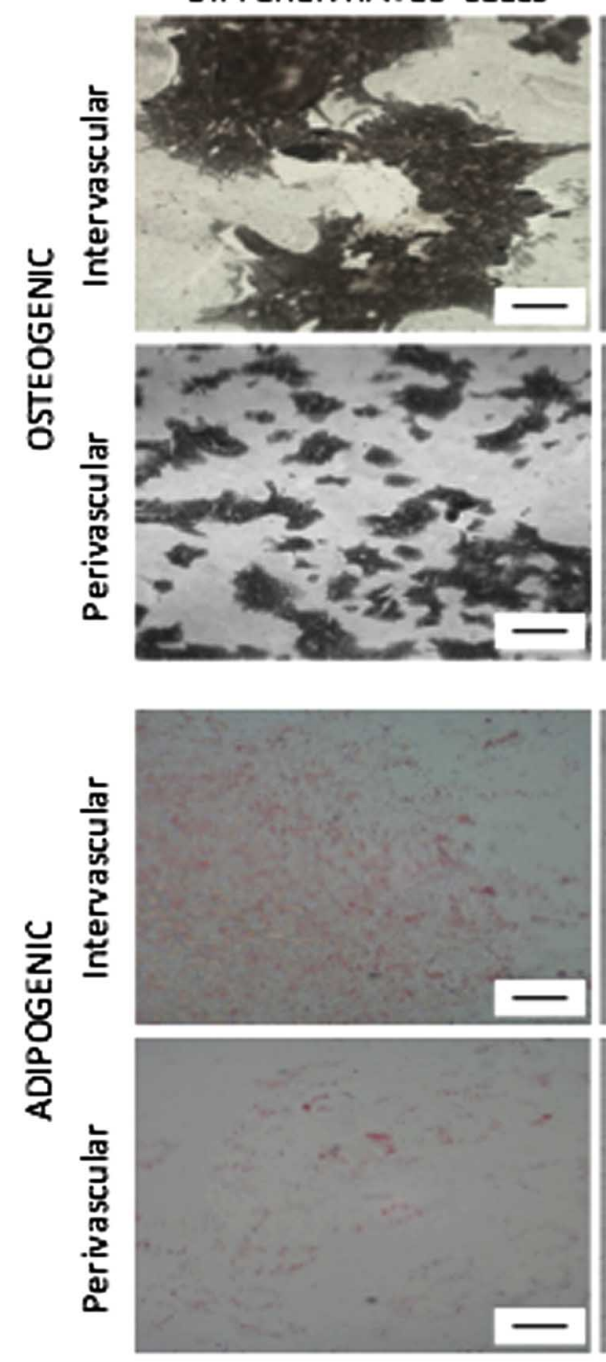

CONTROLS
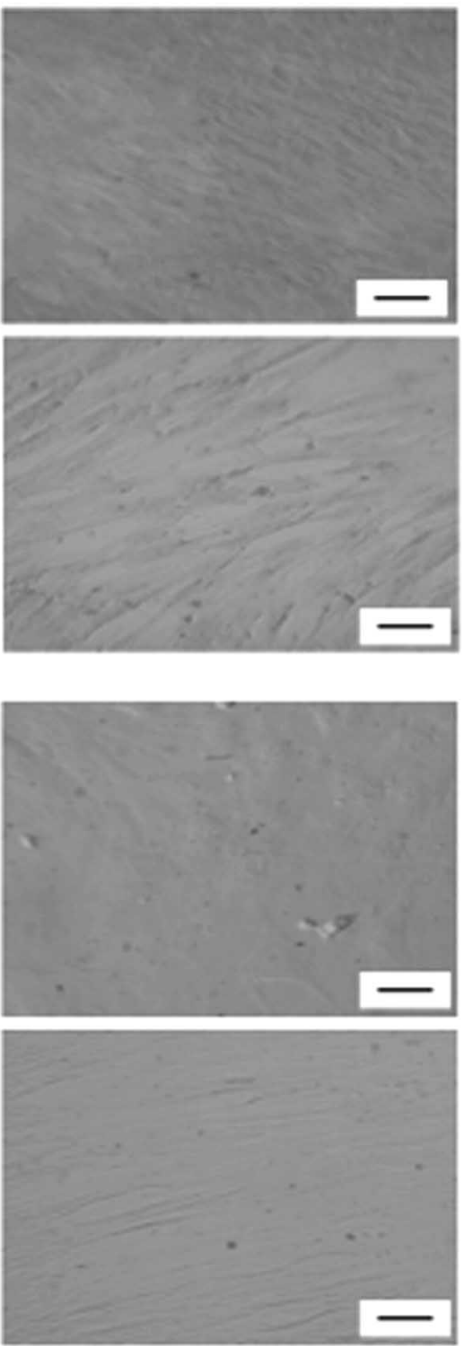
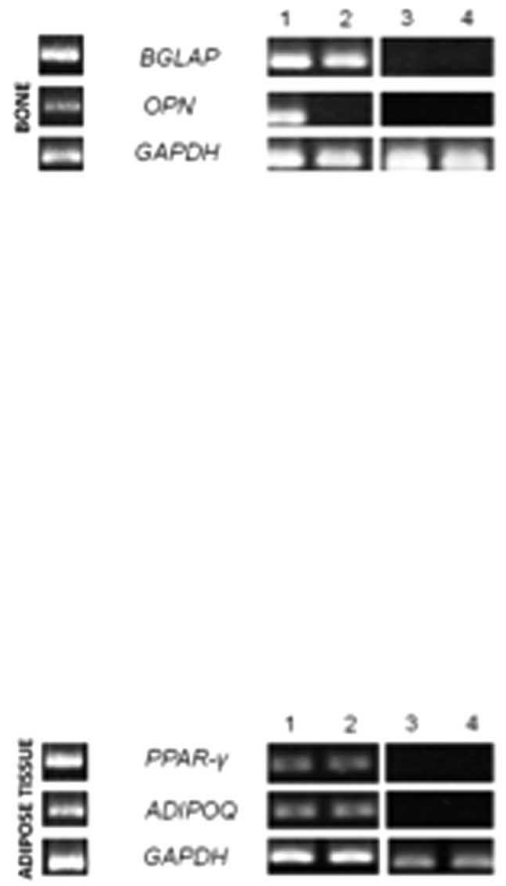

PPAR-Y

AORPOQ

GAPDH

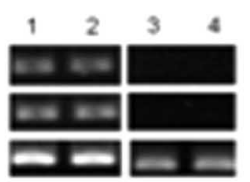



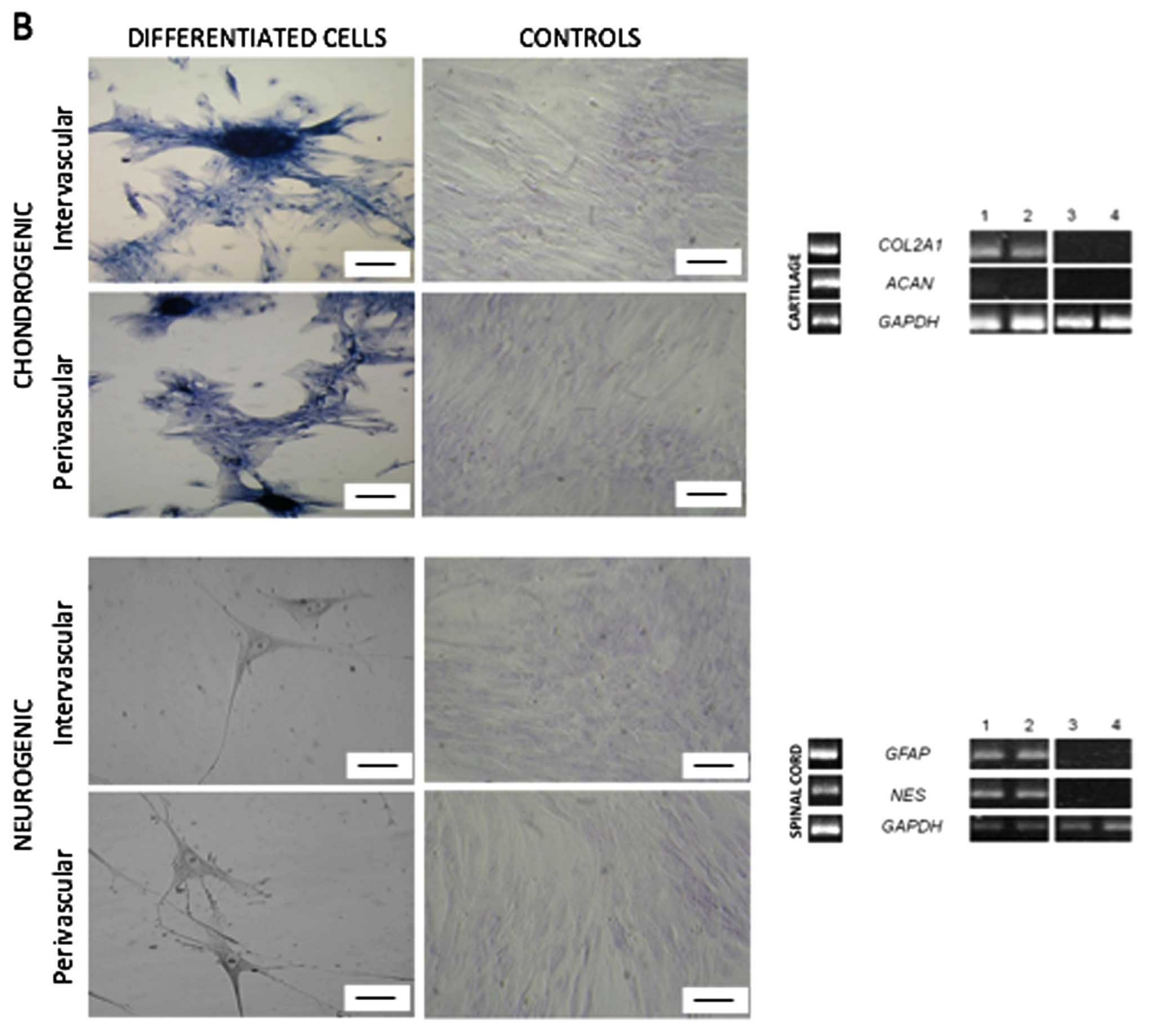

Fig. (6). A) Intervascular- and perivascular- derived cells induced to osteogenic (von Kossa stain) and adipogenic (Oil red O stain) differentiation; B) Intervascular- and perivascular- derived cells induced to chondrogenic (Alcian blue stain) and neurogenic (Nissl stain) differentiation. Undifferentiated cells are reported as controls. 20x magnification. Scale bars: $40 \mu \mathrm{m}$. Panel on the right shows specific gene expression on bone, adipose tissue, cartilage and spinal cord used as positive controls and on intervascular and perivascular cells, induced (1 and 2, respectively) and controls (3 and 4, respectively). BGLAP and $O P N$ mRNA were investigated for osteogenesis, $P P A R Y$ and $A D I P Q$ for adipogenesis, $A C A N$ and $C O L 2 A 1$ for chondrogenesis and $N E S$ and GFAP for neurogenesis. GAPDH was employed as the reference gene.

positive staining for Oil Red $\mathrm{O}$ after 3 weeks of culture in adipogenic induction medium. Control cells, maintained in regular control medium, showed no lipid deposits. RT-PCR analysis of $P P A R-y$ and $A D I P Q$ mRNA expression confirmed adipogenic induction.

\subsubsection{Chondrogenic Differentiation Potential}

Chondrogenic differentiation of cells derived from the inter- and perivascular portions was identified by marked deposition of glycosaminoglycans in the matrix, which was observable after Alcian blue staining. The presence of COL2A1 and ACAN mRNA confirmed chondrogenic induction for both cell populations.

\subsubsection{Neurogenic Differentiation Potential}

After 3 days of induction, neurogenic differentiation was confirmed by the morphology of the cells. The umbilical cord-derived cells adopted the typical morphology of neural cells with dendrite-like processes. The presence of GFAP mRNA suggested that under these culture conditions, UCMderived cells were induced to differentiate into glial cells. Both cell populations showed a decreased NES expression when compared to the positive control (spinal cord).

RT-PCR analysis of equine adult tissues (bone, fat, cartilage and spinal cord) showed expression of the specific genes studied.

\subsection{Contrast Agents Cells Labelling}

\subsubsection{Proliferation Rate}

Fig. (7) shows a comparison, at P3, between cell growth curves of SPIO or $\mathrm{MnCl}_{2}$-labeled cells and control (untreated cells). The lag phase appears to be an important critical stage between labeled cells and control populations; however, during the subsequent proliferative phase, proliferative activity showed no significant changes compared to 


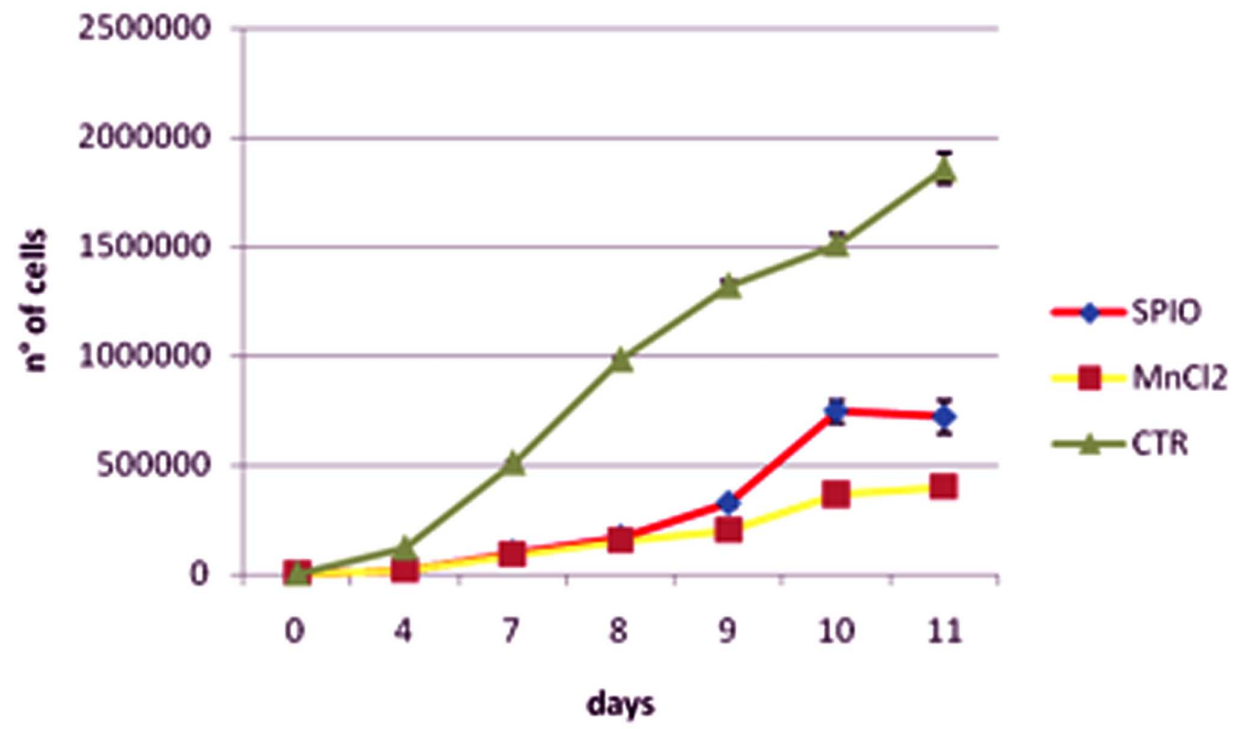

Fig. (7). Comparison of cell growth curves at $\mathrm{P} 3$ between $\mathrm{SPIO}$ and $\mathrm{MnCl}_{2}$-labeled cells and controls (untreated cells).

corresponding unlabeled cells. Doubling time results were similar between control and treated groups with values of $1.04 \pm 0.25$ days for control cells, $1.46 \pm 0.27$ days for SPIOlabeled cells and $1.59 \pm 0.32$ days for $\mathrm{MnCl}_{2}$-labeled cells.

\subsubsection{Prussian Blue Staining}

SPIO-labeling was confirmed by Prussian blue staining that demonstrated iron-containing sites as blue spots in the cytoplasm, when monolayer cells were analyzed. Fig. (8) compares labeled cells at day 1 (A) and at day 8 (B) when intracytoplasmic iron deposits decreased.
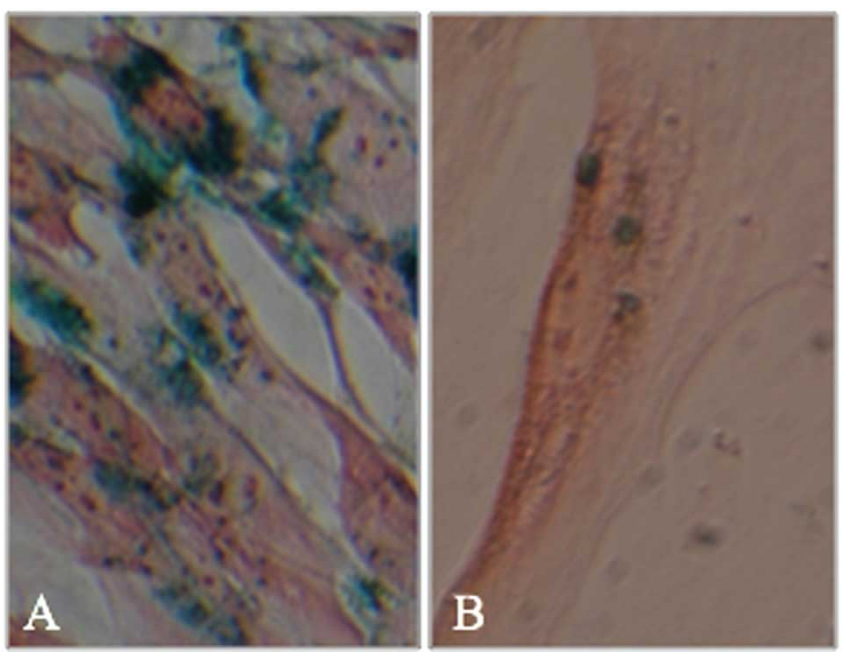

Fig. (8). Blue Prussian staining in SPIO-labeled cells, where ironcontaining sites appear as blue spots in the cytoplasm at 1 (A) and 8 (B) days after labeling.

\subsubsection{Apoptosis Test}

No statistically significant differences were observed in apoptosis rate between $\mathrm{SPIO}-, \mathrm{MnCl}_{2}$-labeled and control cells. Data are shown in Table 2.

\subsection{MRI in vitro}

\subsubsection{MRI of Cell Suspensions}

A scanning artifact (due to the ferromagnetic material corresponding to the tube containing cells labeled with SPIO) was seen on the transverse plane, T1-weighted spinecho sequence (Fig. 9A). On T1-weighted spin-echo sequence scans, cells treated with $\mathrm{MnCl}_{2}$ were markedly hyperintense (Fig. 9B,D-1) with respect to the control that appeared isointense (Fig. 9B,D-2). A marked hypointense signal in tubes containing air was observed (Fig. 9B,D-3,4). The signals were identical in both scans performed in the dorsal and transverse planes. The presence of a hypointense signal on the conical bottom of the tube in the transverse plane scan is related to the presence of a bubble of air, as shown by arrow in Fig. (9C).

\subsubsection{MRI of Isolated Tendons}

\subsubsection{SPIO Labeled Cells}

The spin-echo T1-weighted sequence scans showed moderately high signal intensity in the sagittal portion of the isolated tendon, corresponding to the induced lesion (Fig. 10A). After intralesional injection of SPIO-labeled cells, a hypointense area in the center of the lesion described above was seen (corresponding to the presence of cells labeled with SPIO) (Fig. 10B).

\subsubsection{2. $\mathrm{MnCl}_{2} \underline{\text { Labeled Cells }}$}

The T1-weighted SE sequence scans conducted along the dorsal tendon, showed a hyperintense line in the lateral parasagittal portion, which extended about $2 \mathrm{~cm}$ in a proximo-distal direction, corresponding to the induced lesion (Fig. 10C). In the same sequence, conducted at the same level after injection of $\mathrm{MnCl}_{2}$ labeled-cells, a slight increase of the load signal was observed, mainly coinciding with the presence of $\mathrm{MnCl}_{2}$ labeled- cells (Fig. 10D). 
Table 2. Rates of Viable, Apoptotic, Necrotic and Dead Cells in Control and Labeled Groups after Labeling

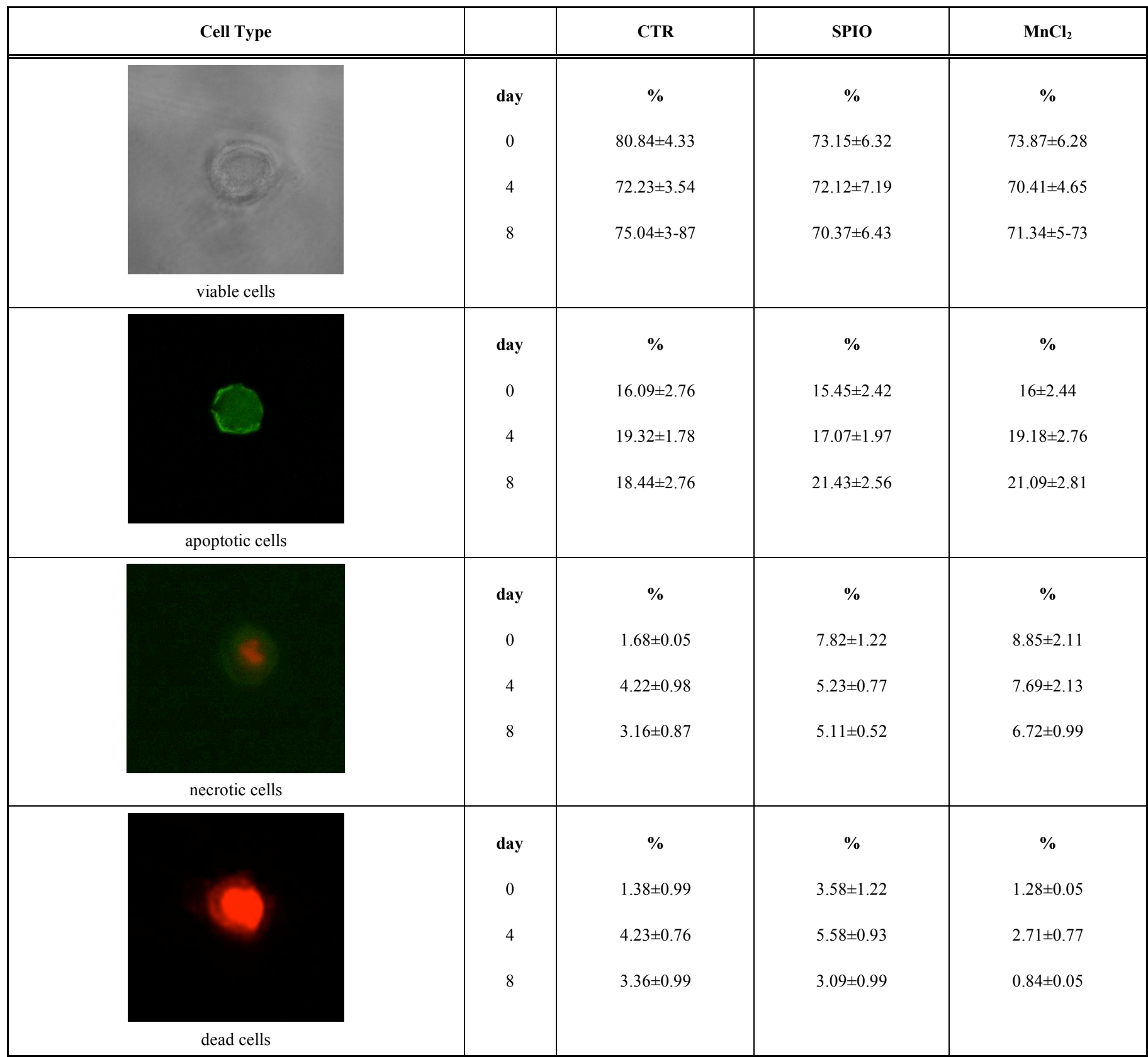

\subsubsection{Control Cells}

The spin-echo T1-weighted sequence scans conducted along the dorsal tendon showed a hyperintense line in the lateral parasagittal portion, which extended about $2 \mathrm{~cm}$ in a proximo-distal direction, corresponding to the induced lesion (Fig. 10E). In the same sequence, conducted at the same level after inoculation of control cells, no changes in signal intensity of the load described above were evident (Fig. 10F).

\section{DISCUSSION}

Umbilical cord shows a tissue compartmentalization with differing cellular characteristics and extra cellular matrix elements. In human medicine, at least six distinct zones have been described based on the structural and functional studies - from outer to inner: (a) surface epithelium (amniotic epithelium), (b) subamniotic stroma, (c) clefts, (d) intervascular stroma or Wharton's jelly, (e) perivascular stroma, and (f) vessels. This study, for the first time, demonstrates isolation and characterization of MSCs from equine intervascular and perivascular UCM and provides additional support for the existence of primitive cells in this tissue. During the primary culture, cells from both areas adhered to the plastic dish surface and showed spindle-shaped fibroblast like morphology. After reaching confluence, some of these cells formed spherical colonies that grew upwards from the surface overlying a layer of confluent cells. We propose that 

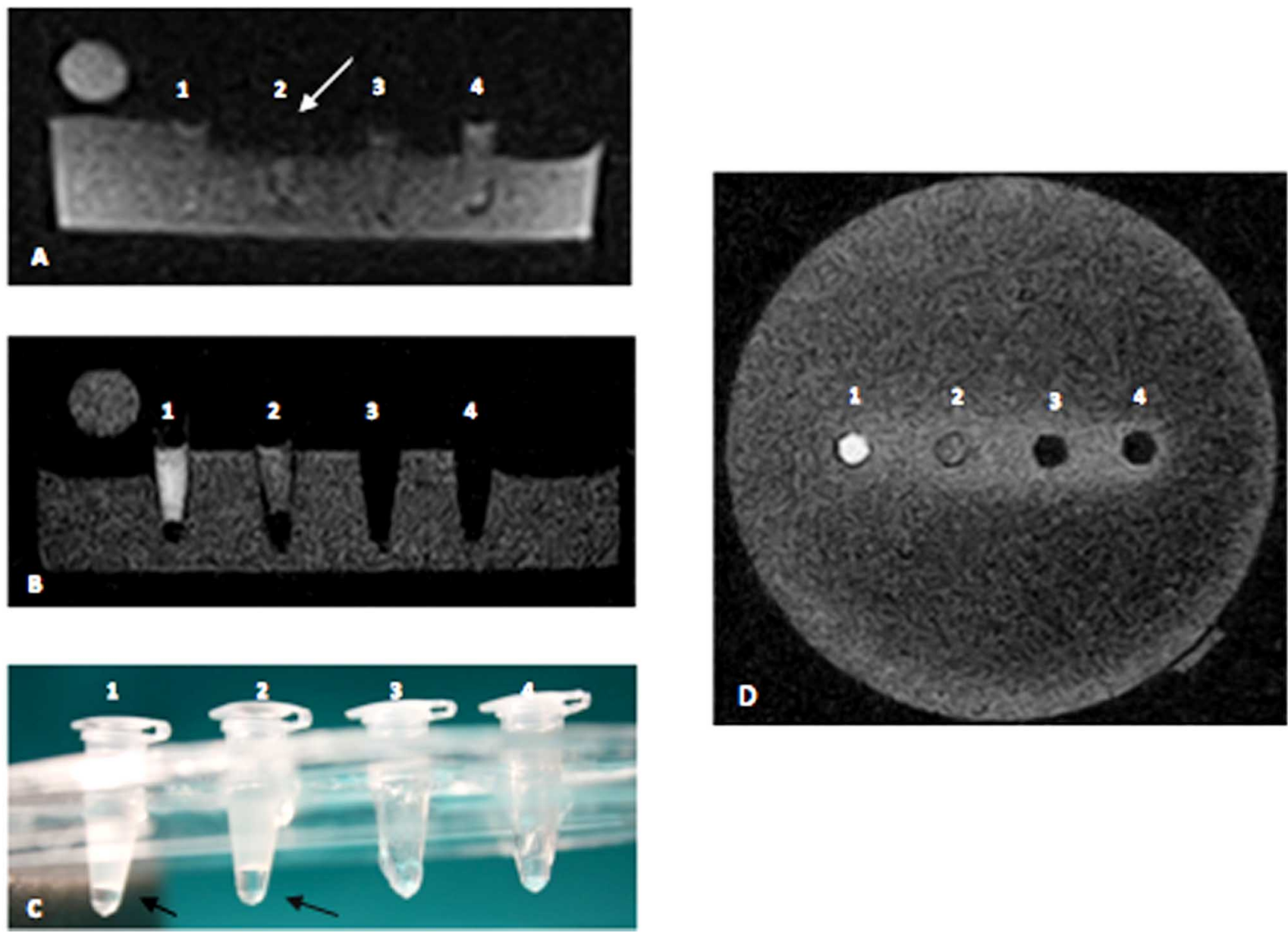

D

Fig. (9). Magnetic resonance imaging of tubes enclosed in phantom gel: A) Transverse view. Tubes n. 1, 3 and 4 controls containing pelleted unlabeled cells. Tubes n. 2, SPIO-labeled horse umbilical cord cells - the arrow indicates the presence of a ferromagnetic material artifact. B) Transverse view. Tube n.1, markedly hyperintense $\mathrm{MnCl}_{2}$-labeled cells and tube n. 2, isointense control pelleted unlabeled cells. The presence of a hypointense signal on the conical bottom of the tubes in the transverse plane scan is related to the presence of a bubble, as shown by arrows in Fig. 9C). Tubes n. 3 and 4: empty tubes. D) Identical signals to figure B shown in dorsal plane view.
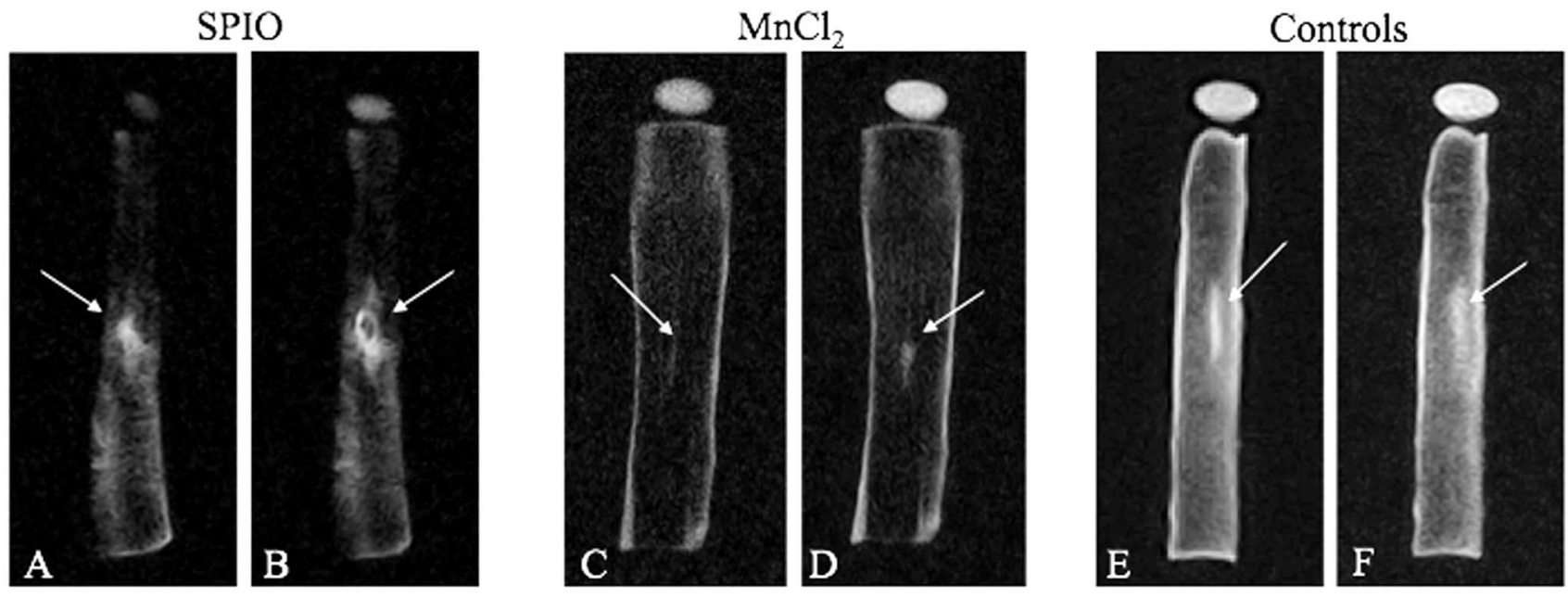

Fig. (10). Magnetic resonance scans of in vitro tendon model. A,C,E) show moderately high signal intensity in the sagittal portion of the middle third of the superficial flexor tendon, corresponding to the induced lesion. B,D,F) After intralesional injection of SPIO-, Mn-labeled and unlabeled cells, it was possible to observe the presence of hypointense, hyperintense and isointense signal intensity areas respectively. 
these colonies represent more primitive progenitor cells, in fact they were similar to the embryoid bodies found in cultures of mouse embryonic stem cells [23]. Cells from the intervascular portion have a faster doubling time and a higher CFU-F frequency than the more differentiated perivascular cells [24]. As reported by Nanaev et al., (1988), the immature cells are located close to the amniotic surface and retain the ability to proliferate, whereas highly differentiated, non-proliferating fibroblasts are located in closer proximity to the vessels [25].

We also investigated the presence of MSC-specific markers (CD44, CD29, CD105, CD166) by RT-PCR and the expression of the hematopoietic markers $(C D 34$ and $C D 14)$ that remained undetectable in terms of presence of mRNA. This pattern was conserved through the passages, from P1 to P10 in cells from both portions of UCM.

To assess the potential of UCM cells in cellular therapy, we evaluated the expression of cell immunogenicity markers including $M H C-I$ and $M H C-I I$. In contrast with the negative results obtained by Hoynowski et al., in 2007 [11], in this study positive results were obtained for $M H C-I$ expression in terms of mRNA. In line with most publications $[26,27]$ no cell populations tested positive for $M H C-I I$ expression from $\mathrm{P} 1$ to $\mathrm{P} 10$, suggesting a potential role of $\mathrm{UCM}$ as an allogenic cell source for cell-based therapies. It is important to underline that Hoyonowski et al., tested expression of MHC-I by flow cytometry and that, to date, commercial antibodies recognizing equine epitopes are only available for CD13, CD44 and MHC-II. This different methodological approach could explain the conflicting result. The unequivocal immunophenotyping of equine MSC is hampered by the lack of a single specific marker and by the limited availability of monoclonal anti-horse antibodies, which are two major factors complicating successful research in this species [28].

Differentiation data confirmed the cells to be progenitors for mesodermic (including osteogenic, adipogenic and chondrogenic) and ectodermic (neurogenic) lineages. After 10 days of osteogenic induction, we detected the presence of $B G L A P$ mRNA in both cell populations. However, only intervascular cells expressed $O P N$, suggesting that these cells differentiated more rapidly (since this gene is highly expressed during matrix maturation and mineralization phases [29]). Committed equine UCM-derived populations gave rise to both chondrogenic and adipogenic lineages, although the literature suggests that equine MSCs show inefficient differentiation into adipogenic lineages compared to human and rodent MSCs. This discrepancy may be due to the heterogeneity of the starting population [30] and/ or culture conditions [23] in previous studies. Furthermore, in this study we were able to show morphologically neuron-like cells and expression of specific neuronal markers after differentiation in vitro. Expression of the classical GFAP was detected suggesting that astrocyte differentiation occurred. The presence of nestin, a marker expressed in neuroepithelial neuronal precursor stem cells, was also investigated and a weak expression was observed, probably due to a long term differentiation (more than 1 day) [21]. In fact, the expression of the nestin gene decreases with neuronal maturation [31].
These data confirm that like human UCM, equine UCM represents an attractive source of MSCs with rapid proliferation and multipotent differentiation properties for regenerative medicine. In particular, cells from the intervascular portion appear to show better proliferation capabilities and faster differentiation in osteogenic lines than the more highly differentiated perivascular cells.

To better understand the potential of UCM-derived cells for cell therapy strategies in various pre-clinical experiments, we evaluated the efficiency and toxicity of labeling cells for MRI. Cells were labeled with magnetic resonance contrast agents such as superparamagnetic iron oxide (SPIO) particles and manganese chloride. SPIO are nanoparticles that do not adhere to the cell membrane without modification of the surface charges. Thus, ferumoxide was combined with protamine sulfate [32], a transfection agent that binds to the dextran coat through electrostatic interactions. This link modifies the ferumoxide distribution of positive and negative surface charges that can adhere to the cell membrane, and creates stable complexed nanoparticles capable of effective labeling cells through endosomal capture.

Manganese, however, enters the cell through the voltagegated $\mathrm{Ca}_{2}{ }^{+}$channels and it is accumulated intracellularly in biologically active cells.

In our in vitro experiment, $\mathrm{MnCl}_{2}$ labeled-cells were markedly hyperintense with respect to the control cells that appeared isointense on MRI scans, while SPIO-labeled cells produced an artifact due to the ferromagnetic material. Whereas, in isolated tendons with artificial lesions that appeared hyperintense, the hypointense area in the center of the lesion (corresponding to the SPIO labeled-cells) was more visible than the signal produced by $\mathrm{Mn}^{2+}$-labeled cells.

Manganese is not approved for clinical use because of its cytotoxicity; however, the concentration used, as suggested by Chung et al., (2009), minimized the cytotoxic effects. Indeed, neither SPIO nor manganese resulted in any adverse effects on cell viability and proliferation with respect to the unlabeled cells (control) [22].

Both contrast agents were found to provide simple, robust and safe methods to label cells; nevertheless, the sensitivity/ability to detect the anatomical location of the cells inside the tendon was higher with the SPIO-labeling method.

There are, however, some limitations to the use of MRI to track transplanted stem cells after labeling with SPIO. Stem cells are characterized by a high proliferation and differentiation ability. Labeled stem cells may also divide asymmetrically resulting in a dilution of their cytoplasm. In this situation, cells cannot be tracked for so long. Indeed, Prussian blue staining confirmed the success of cell labeling with SPIO at day 1 , with visible intracytoplasmic deposits of this contrast agent, but the incorporation of SPIO decreased at day 8 probably due to mitotic division or to exocytotic processes. Such a decrease in contrast concentration is a limitation in following the homing of cells in vivo. Moreover, it is important to take into account that for in vitro imaging experiments, isolated tendons were used, with an artificial lesion that appeared hyperintense in the physio- 
logically hypointense structures of tendons. In this situation, unlike in vivo, there is no inflammatory process that may modify the signal intensity of the lesion area and the appearance of labeled-cells.

In order to overcome the limitations of these in vitro studies, further in vivo studies using both SPIO and manganese agents are required to assess cell distribution and migration after injection into spontaneous lesions.

\section{CONCLUSION}

This study demonstrates that equine UCM is an easily accessible tissue containing a significant quantity of progenitor stem cells which are attractive for tissue regeneration studies because of their multilineage differentiation, high proliferation potential and negativity for $M H C I I$ expression. Moreover, labeled cells can be detected by MRI in vitro, allowing this experimental setting to be used as a model for clinical trials investigating the temporal and spatial migration of mesenchymal stem cells into tissues and their potential for long-term survival.

\section{ABBREVIATIONS}

$$
\begin{aligned}
& \mathrm{BM}=\text { Bone marrow } \\
& \mathrm{DT}=\text { Doubling time } \\
& \mathrm{MRI}=\text { Magnetic resonance imaging } \\
& \mathrm{MSCs}=\text { Mesenchymal stem cells } \\
& \text { Pro }=\text { Protamine sulfate } \\
& \mathrm{SPIO}=\text { Superparamagnetic iron oxide particles } \\
& \mathrm{UCM}=\text { Umbilical cord matrix }
\end{aligned}
$$

\section{ACKNOWLEDGEMENTS}

Donatella De Zani, DVM, is kindly acknowledged for her skilled MRI ability.

\section{CONFLICT OF INTEREST}

None declared.

\section{REFERENCES}

Dyson SJ. Medical management of superficial digital flexor tendonitis: a comparative study in 219 horses (1992-2000). Equine Vet J 2004; 36: 415-9.

[2] D'Ippolito G, Howard GA, Roos BA, Schiller PC. Sustained stromal stem cell self-renewal and osteoblastic differentiation during aging. Rejuvenation Res 2006; 9: 10-9.

[3] Kern S, Eichler H, Stoeve J, Kluter H, Bieback K. Comparative analysis of mesenchymal stem cells from bone marrow, umbilical cord blood, or adipose tissue. Stem Cells 2006; 24: 1294-301.

[4] Vidal MA, Walker NJ, Napoli E, Borjesson DL. Evaluation of senescence in mesenchymal stem cells isolated from equine bone marrow, adipose tissue, and umbilical cord tissue. Stem Cells Dev 2011; [Epub ahead of print].

[5] Bajada S, Mazakova I, Richardson JB, Ashammakhi N. Updates on stem cells and their applications in regenerative medicine. J Tissue Eng Regen Med 2008; 2: 169-83.

[6] Siegel N, Rosner M, Hanneder M, Valli A, Hengstschlager M. Stem cells in amniotic fluid as new tools to study human genetic diseases. Stem Cell Rev 2007; 3: 256-64.
[7] Marcus AJ, Woodbury D. Fetal stem cells from extra-embryonic tissues: do not discard. J Cell Mol Med 2008; 12: 730-42.

[8] Carlin R, Davis D, Weiss M, Schultz B, Troyer D. Expression of early transcription factors Oct-4, Sox-2 and Nanog by porcine umbilical cord (PUC) matrix cells. Reprod Biol Endocrinol 2006; 4: 8 .

[9] Corradetti B, Lange Consiglio A, Barucca M, Cremonesi F, Bizzaro D. Isolation and characterization of size-sieved mesenchymal stem cells (MSCs) from perivascular and intervascular Wharton's Jelly of horse humbilical. Cell Proliferation 2011(doi:10.1111/j.1365-2184.2011.00795.x): in press.

[10] Cremonesi F, Violini S, Lange Consiglio A, Ramelli P, Ranzenigo $\mathrm{G}$, Mariani P. Isolation, in vitro culture and characterization of foal umbilical cord stem cells at birth. Vet Res Commun 2008; 32: 13942.

[11] Hoynowski SM, Fry MM, Gardner BM, et al. Characterization and differentiation of equine umbilical cord-derived matrix cells. Biochem Biophys Res Commun 2007; 362: 347-53.

[12] Passeri S, Nocchi F, Lamanna R, et al. Isolation and expansion of equine umbilical cord-derived matrix cells (EUCMCs). Cell Biol Int 2009; 33: 100-5.

[13] Toupadakis CA, Wong A, Genetos DC, et al. Comparison of the osteogenic potential of equine mesenchymal stem cells from bone marrow, adipose tissue, umbilical cord blood, and umbilical cord tissue. Am J Vet Res 2010; 71: 1237-45.

[14] Mitchell KE, Weiss ML, Mitchell BM, et al. Matrix cells from Wharton's jelly form neurons and glia. Stem Cells 2003; 21: 50-60. Anzalone R, Lo Iacono M, Loria $\mathrm{T}$, et al. Wharton's Jelly mesenchymal stem cells as candidates for beta cells regeneration: extending the differentiative and immunomodulatory benefits of adult mesenchymal stem cells for the treatment of type 1 diabetes. Stem Cell Rev 2011; 7: 342-63.

[16] Weiss ML, Medicetty S, Bledsoe AR, et al. Human umbilical cord matrix stem cells: preliminary characterization and effect of transplantation in a rodent model of Parkinson's disease. Stem Cells 2006; 24: 781-92.

[17] Carrade DD, Owens SD, Galuppo LD, et al. Clinicopathologic findings following intra-articular injection of autologous and allogeneic placentally derived equine mesenchymal stem cells in horses. Cytotherapy 2011; 13: 419-30

[18] Romanov YA, Svintsitskaya VA, Smirnov VN. Searching for alternative sources of postnatal human mesenchymal stem cells: candidate MSC-like cells from umbilical cord. Stem Cells 2003; 21: $105-10$.

[19] Soncini M, Vertua E, Gibelli L, et al. Isolation and characterization of mesenchymal cells from human fetal membranes. J Tissue Eng Regen Med 2007; 1: 296-305.

[20] Seo MS, Jeong YH, Park JR, et al. Isolation and characterization of canine umbilical cord blood-derived mesenchymal stem cells. J Vet Sci 2009; 10: 181-7.

[21] Woodbury D, Schwarz EJ, Prockop DJ, Black IB. Adult rat and human bone marrow stromal cells differentiate into neurons. J Neurosci Res 2000; 61: 364-70.

[22] Chung J, Yamada M, Yang PC. Magnetic resonance imaging of human embryonic stem cells. Curr Protoc Stem Cell Biol 2009; Chapter 5: Unit 5A 3.

[23] Reed SA, Johnson SE. Equine umbilical cord blood contains a population of stem cells that express Oct4 and differentiate into mesodermal and endodermal cell types. J Cell Physiol 2008; 215: 329-36.

[24] Karahuseyinoglu S, Cinar O, Kilic E, et al. Biology of stem cells in human umbilical cord stroma: in situ and in vitro surveys. Stem Cells 2007; 25: 319-31.

[25] Nanaev AK, Kohnen G, Milovanov AP, Domogatsky SP, Kaufmann P. Stromal differentiation and architecture of the human umbilical cord. Placenta 1997; 18: 53-64.

[26] Deans RJ, Moseley AB. Mesenchymal stem cells: biology and potential clinical uses. Exp Hematol 2000; 28(8): 875-84.

[27] Dominici M, Le Blanc K, Mueller I, et al. Minimal criteria for defining multipotent mesenchymal stromal cells. The International Society for Cellular Therapy position statement. Cytotherapy 2006; 8: 315-7.

[28] De Schauwer C, Meyer E, Van de Walle GR, Van Soom A. Biology and therapeutic use of domestic animal stem cells. Markers of stemness in equine mesenchymal stem cells: a plea for uniformity. Theriogenology 2011; 75: 1431-43. 
[29] Raouf A, Seth A. Ets transcription factors and targets in osteogenesis. Oncogene 2000; 19: 6455-63.

[30] Koerner J, Nesic D, Romero JD, Brehm W, Mainil-Varlet P, Grogan SP. Equine peripheral blood-derived progenitors in comparison to bone marrow-derived mesenchymal stem cells. Stem Cells 2006; 24: 1613-9.
[31] Lendahl U, Zimmerman LB, McKay RD. CNS stem cells express a new class of intermediate filament protein. Cell 1990; 60(4): 58595.

[32] Arbab AS, Yocum GT, Kalish H, et al. Efficient magnetic cell labeling with protamine sulfate complexed to ferumoxides for cellular MRI. Blood 2004; 104: 1217-23.

(C) Lange-Consiglio et al.; Licensee Bentham Open.

This is an open access article licensed under the terms of the Creative Commons Attribution Non-Commercial License (http://creativecommons.org/ licenses/by-nc/3.0/), which permits unrestricted, non-commercial use, distribution and reproduction in any medium, provided the work is properly cited. 